\title{
The Relationship Between Creativity And Dancing Ability
}

\author{
Sri Wulan Anggraeni ${ }^{\text {a,1 }}$, Aang Solahudin Anwar ${ }^{\text {a, } 2}$, Sri Rahayu ${ }^{\text {a }}$ \\ ${ }^{a}$ Department of Primary School Education, Universitas Buana Perjuangan Karawang \\ ${ }^{1}$ wulan.anggraeni@ubpkarawang.ac.id, ${ }^{2}$ aang.solahudin@ubpkarawang.ac.id *
}

\begin{abstract}
The problem in this research is the low ability of students to dance. This can be seen from the teacher has not stimulated students in dancing and the lack of student creativity in creating dance movements. This research aims to test the significance of the relationship of creativity with the ability to dance in students' elementary school. This research is a correlational study using a quantitative approach. Data collection techniques through creative tests and dance skills test. Analytical techniques using prerequisite analysis tests include normality testing, linearity test, and hypothesis testing using the product-moment correlation analysis with the level of significance of the analysis results by $5 \%$. Based on the results, the study showed that there was a positive and significant relationship between creativity and the ability to dance fourth-grade students of elementary school. This is evidenced by the significance of the $0.02(\mathrm{P} \leq 0.05)$, meaning there is a positive relationship between creativity and the ability to dance.
\end{abstract}

Keywords:

Creativity, Dancing ability

\section{INTRODUCTION}

Child motor capability is the development of a maturity element that can be shaped by an activity. As the physical growth matures, the child's motor development can be well coordinated. Each movement is in line with his needs and interests. Motor capability can be improved again through the activity of the child. Activities in the child can be a movement of limbs with a clear purpose, such as moving the hand to write, drawing, taking food, throwing balls, and so on. Activities in the child can be a movement of limbs with a clear purpose, such as moving the hand to write, drawing, taking food, throwing balls, and so on. According to Yusuf Syamsu (2014:59) said that "in elementary school- age children (7-12 years) is characterized by agile movements and motor activity." Therefore, in this age period is an ideal time for skills related to the motor of the child, both the motor that is smooth and coarse. Smooth motor development can be written, draw, paint, type, sew and make crafts from paper. In addition to fine motor, crude motor development can be lined lines, martial arts, gymnastics, swimming, and dancing.

Dancing is a beautiful motion of all the limbs accompanied by rhythmic songs and has a certain intention to emulate the natural atmosphere. The natural atmosphere reveals the expression of human souls through motion media. This is in line with Soedarsono stating that the dance is the expression 
of the human psyche through beautiful rhythmic motion (Anggraeni and Alpian 2018:01).

The art of dance in education, especially elementary school education has a positive impact, Not only from the various art conservation efforts, but also for the sake of education itself is able to develop skills that have, and can improve the physical and motor development better in children. In addition, dance arts education can make a child's achievement in school. Dancing has some physical elements that must be developed through practice. The elements that must be prepared include strength, speed, endurance, coordination, and accuracy.

For the Aged child (9-10 years), he can develop his own talent potential by creating a movement through the expression of a soul or a motion media. We, as a prospective educator, must need knowledge not only in the field of subjects, but the art of dance must also be understood. The skill of a teacher in understanding the characteristics of an elementary school child is indispensable. Therefore, for students who have such potential will be developed again by the teacher to be able to have skills in the field of dancing. Dancing has some physical elements that must be developed through practice. The elements that must be prepared include strength, speed, endurance, coordination, and accuracy. With the fulfillment of these elements, it will form a balance of motion in the dancers.

But in fact, the ability to dance on elementary school fifth-grade students at Karawang is still low. Based on the observations conducted on 03
December 2018 showed that students have difficulty in dancing skills. This is due to external factors and internal factors. Judging by external factors, there is no teacher who can train students and lack of venue facilities and media in the form of speakers to teach their students to practice so that they can impede the process of training students in dancing. In addition, it is seen from the internal factor that the creativity of students is low in mastering the dance moves so that students are limited in thinking to develop and create new movements and difficult to adjust the movement with the music.

Mountakis (Munandar, 2014:17) expressed creativity that is a knowledge that can reveal new personal traits to individuals, outside environment, and so on. Thus, creativity is an ability that can produce a work of his own thoughts. Aside from the results of his own thinking, creativity can be generated with a new image that can be seen in his daily life. According to Guilford (Munandar,2014:65) said that creativity is a divergent thought as a mental operation that demands the use of creative thinking skills, including smoothness, flexibility, originality, and elaboration (breakdown).

Thus, the dancing skills need to be supported by creativity in creating exciting dance movements; people who have high creativity will have different dance concepts with others, have novelty and authenticity. So the results of the dance movement that is the process of the child's creativity will be an interesting dance movement and different from the others. 
Based on the problems and research results used that researchers are interested in reviewing the problems that exist at SDN 1Telukjambe on learning Dancing with the title "Relationship of creativity with the ability to dance."

\section{LITERATURE REVIEW}

\section{Dancing Ability}

Dancing is an expression of the human soul expressed by beautiful rhythmic movements. Someone who is doing a dance is called a dancer. Dancing is not the same as playing games, having anonymity, or exercising. Someone can be said to dance when they realize that they are dancing, not playing, not exercising. Someone is called dancing when he realizes that he is expressing something through the dance that is being danced. Something that can be in the form of ideas, feelings, experiences, thoughts and not move spontaneously, because someone who is dancing moves based on movements that have been arranged and arranged (Soedarsono, 2002: 01).

Dance can be interpreted as the beauty of the motion of the members of the human body that is moving, rhythmic, and soulful. Soedarsono stated that dance is an expression of the human soul through beautiful rhythmic movements (Anggraeni and Alpian, 2018: 01). Dance can express the soul's expression and can convey a certain meaning to be expressed to others. The phrase can be a symbolic or abstract expression that is difficult to understand or express. However, all these elements are aesthetic elements.
Dance According to Widaryanto (2007:4) is a patterned movement. The motion in question is a movement that does not just move but has a certain pattern that forms a composition. Dance is referred to as the most ancient art. That is, the most important element in the dance is motion, but it is different from the everyday movements of the day. The motion in the dance is a pure motion that has been distillation into a motion that has meaning

Soedarsono said that every movement expressed in a dance contains a certain character. For example, if a dancer would describe crying. He will use meaningful motion by covering his face and shrinking his body. In this kind of motion, the audience will easily get the impression that the dancer is describing crying. This impression becomes clear because the dancer shrinks or wrinkles her body by bending her legs and slightly bending her body to the floor in a closed arm position (Anggraeni and Alpian 2018: 07).

When depicting a story, a dancer must be able to master and integrate three main elements: Wiraga, Wirama, and Wirasa (Haryono, 2012:29). Three main elements become a whole in accordance with the dance character presented. Between the dance moves of a dancer, the execution of the dance rhythm, and the dancer's dancers to the content or meaning or flavor contained is a unit of interlocking hooks firmly. It means a dancer actually dances a dance when it is able to display the relationship of the three elements between the phrases or the parts that are done in total. 
According to Soeryodiningrat (Panggayuh, put all the capabilities that exist by producing H.C.,2012:22) Dance-forming elements Wiraga, something positive and useful and keep trying to Wirama, Wirasa, Wirupa. Wiraga is the basic skill of develop in order to become even better. This can body gestures/physic dancers. Wirasa is a level of be achieved if we channel our abilities optimally passion and psychiatric in the dance, such as firm, gentle, joyful, and sad, which expresses it through the movement and facial nose that gives birth to beauty. Wirupa is a dancer's appearance from the upper end to the lower end.

As for the dance elements, according to Anggraeni and Alpian (2018: 21), there are four basic elements in dance, namely the elements of motion, energy, space, and time. These elements are unity in dance. Motion can create the impression that is formed, and energy can control and stop motion space is the main element that determines the realization of a movement, and time is the element that forms dance movements.

Based on some of the above theories, it can be concluded that the ability to dance is the ability to express the soul through rhythmic movements that can create beautiful movements by paying attention to aspects of motion, energy, space, and time.

\section{Creativity}

Creativity is a lifestyle and a way of perceiving the world. A creative life means developing all the talents they have, learning to optimize their own abilities, exploring new ideas, new places, new activities, developing sensitivity to existing problems around such as environmental problems, other people's problems, and humanitarian problems. Developing the talents possessed means trying to (Munandar. 2014: 19).

Drevdahl (in Prastini, D. 2015:9) reveals that "creativity is a person's ability to produce new compositions, products, or ideas that were not previously recognized by their own." It is more pointed towards creativity to create new, more interesting, and renewable works. Create original and unprecedented work. A person can be said to be creative when the person can create a new product or original work with a new idea and has never existed before.

Musbikin (spiritual. 2017:12) creativity is the ability to start an idea, see a new or unexpected relationship, the ability to formulate a concept that is not just memorizing, creating a new answer to solve existing problems, and Get new questions to answer. Creativity is essential to be cultivated and developed in the child because with the creation of people, it can manifest itself, and the self-embodiment, including one of the basic needs in human life. Creativity or thought, as the ability to see a variety of possible solutions to a problem, is a form of thought that, until now, still lacks attention informal education.

According to Guilford (Munandar, 2014:65) revealed that creativity involves divergent thinking as a mental operation that demands the use of creative thinking skills, including smoothness, flexibility, originality, and elaboration (breakdown). People who 
are high in fluency will produce many ideas in solving problems; people who are tall in flexibility can easily adapt the idea of problem-solving that has been used if a new problem demands a New. People who are high in originality can produce new ideas that are unique and unusual. Elaboration is the ability to add detail to the underlying idea generated.

Creativity is an important factor in determining the success of student learning. This fact is in line with the Slameto (1995:25) that the student's creativity factor affects the learning outcomes of students. This is according to Nana (2004:45) because creative students have a personality such as learning more independent, responsible, hard work, motivated, optimistic, have a great curiosity, confidence, open, Have tolerance, and are rich in thought. All these personalities are indispensable for each student in the learning process to develop their creativity and achieve optimal learning outcomes.

Likewise, in the development of creativity can be developed through dance movements. Hawkins (in Prastini, D.2015:15) Explains, "creativity can be developed through exploration of the motion materials and also through the organization of Motion to the formed dance. Technical and creative work has to walk in hand. While the purpose of engineering is to serve the creator's needs, studies must arise from expressive needs. " Hawkins (In Hadi, 2011:139) also explains that creating a new dance is a creative activity. During the process, the choreographer explores the sense of data and feelings about its perception. The choreographer processed the materials and the imaginative responses and transformed into his imaginary conception, and when the imagination gave the shape, it would create motion in a new dance.

Based on the foregoing, it can be concluded that creativity is a mental process involving the discovery of new ideas or concepts or the relationship between new concepts with existing concepts by developing some aspects that include Pernyataan ( Authenticity), fauncy (smoothness), flexibility (suppleness), and elaboration.

\section{METHODOLOGY}

The type of research that will be used is quantitative research. According to Sugiyono (2013:13), Quantitative research method is a method of research that there is a study data in the form of numbers and analyzed using statistics. The research design to be used is correlation research.

This research aims to know the relationship of creativity to the students ' dancing skills in class IV of SDN Telukjambe I. In this research researchers just wanted to know the relationship of variable $X$ and $Y$ by spreading the test of creativity and the ability to dance

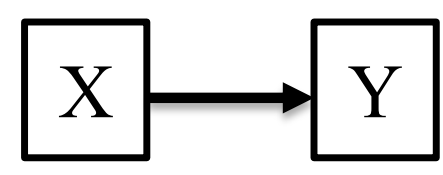

Figure 1. Design Research (Sukardi,2012:166)

Description:

$X=$ Creativity

$Y=$ dancing ability

The data collection techniques in this study used a test instrument i.e., creativity Test and 
danceability test. The assessment is done according to the indicator of each variable. The validity of the instrument dances using the validity of the construction that is consulted on experts (expert judgment) to be examined and evaluated. While the validity of the instrument of creativity using validates construction and its contents with the formula used is a correlation coefficient point biserial. And the instrument reliability testing using the Cronbach Alpha formula.

The data analysis techniques in this research are using statistical calculations that are descriptive statistics and inferential statistics by testing the normality, linearity test, and hypotheses test that will be conducted using a correlation test Product Moment

\section{RESULT AND DISCUSSION}

Descriptive analysis results

This descriptive statistical analysis aims to provide an overview of the data obtained in each variable. The data presented are mean, median, mode, standard deviation, highest score, lowest score.

\section{Dancing ability}

Based on data obtained through a danceability test with 30 respondents. Scoring is performed on criteria that are in accordance with procedures and approved by experts (Expert judgment).

The theoretical score ranges from 20 to 100 . Based on collected observation data, a maximum score of 90 and a minimum score of 65 is obtained, averaging 78.83, standard deviation (SD) 7.844, mode (Mo) 85, median (Me) 80; and variant 61.52. The distribution of dancing ability variables is presented in table 1 as follows.

\section{Table 1. Data description of the ability to dance}

Statistics

\begin{tabular}{|c|c|c|}
\hline \multicolumn{3}{|c|}{ Dancing Ability } \\
\hline \multirow{2}{*}{$\mathrm{N}$} & Valid & 30 \\
\hline & Missing & 0 \\
\hline Mean & & 78,83 \\
\hline \multicolumn{2}{|c|}{ Std. Error of Mean } & 1,432 \\
\hline \multicolumn{2}{|l|}{ Median } & 80,00 \\
\hline \multicolumn{2}{|l|}{ Mode } & 85 \\
\hline \multicolumn{2}{|c|}{ Std. Deviation } & 7,844 \\
\hline \multicolumn{2}{|l|}{ Variance } & 61,523 \\
\hline \multicolumn{2}{|l|}{ Range } & 25 \\
\hline \multicolumn{2}{|l|}{ Minimum } & 65 \\
\hline \multicolumn{2}{|l|}{ Maximum } & 90 \\
\hline \multicolumn{2}{|l|}{ Sum } & 2365 \\
\hline
\end{tabular}

2. Creativity

Data on creativity variables are obtained by using instruments in the form of creativity test questions. The instrument in the form of the test was filled by 30 respondents who had 30 questions. Each question has five alternative answers chosen by the respondent. Based on data obtained through creativity tests, the range of theoretical scores is between 30 and 150. Based on the collected observation data, a maximum score of 90 and a minimum score of 50 was obtained, averaging 
73.07, standard deviation (SD) 9.54, mode (Mo)

64 , median (Me) 74, and variants of 90.96 .

\section{Table 2. Data description of creativity}

Statistics

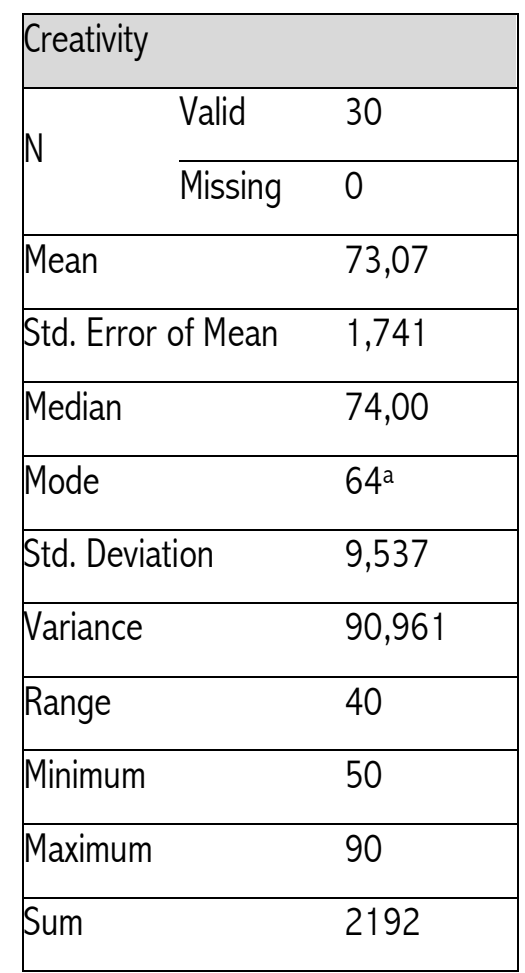

a. Multiple modes exist. The

smallest value is shown

3. Analysis Prerequisite test result

\section{a) Normality Test}

Normality calculation is used to find out whether a data distribution is normal. The normality test in this study was calculated using the Kolmogorov Smirnov formula. If the sig value is $>$ 0.05 , then the data is normally distributed, while if the sig value $<0.05$, the data is not normally distributed. The calculation of normality test results can be seen in the following table.
Table 3. Normality Test

One-Sample Kolmogorov-Smirnov Test

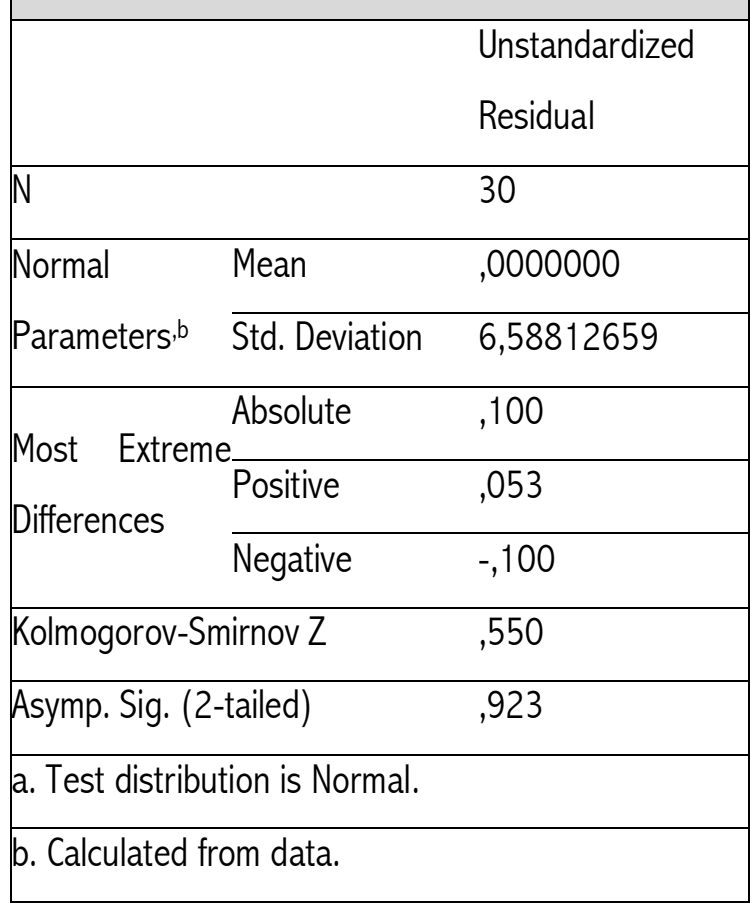

Normality calculation is used to find out whether a data distribution is normal. The significance value of the relationship of creativity with the dancing ability on Asymp. Sig. (2-tailed) of $0.923>0.05$. Then, in accord with the basis for decision making in the Kolmogorov-Smirnov normality test above, it can be concluded that the data are normally distributed.

\section{b) Linearity Test}

The linearity test is used to determine whether the relationship between two linear variables. A linear relationship is characterized by an increase in scores on a variable followed by an increase in other variables. If the sig value is obtained. Linearity $<0.05$ and sig. Deviation from linearity $>0.05$, then the relationship between linear variables. The results of the linearity test analysis can be seen in table 4 . 
Table 4. Linearity Test

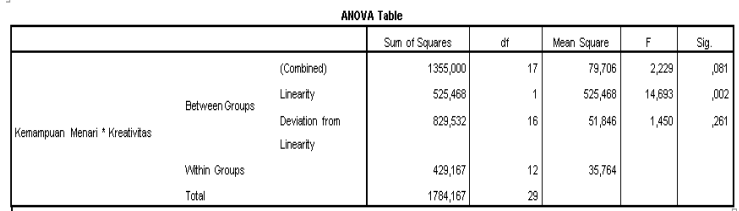

Based on the table above, the sig. Linearity in the relationship of creativity with the dancing ability of 0.261 . This value is greater than 0.05 . Thus, it can be concluded that the relationship of creativity with dancing ability goes linear

\section{c) Hypothesis Test Results}

Hypothesis testing is done using Pearson's Product Moment Correlation formula. The criterion for accepting or rejecting a hypothesis is to look at the acquisition price of $r$ with $r_{\text {table }}$ at a significance level of $5 \%$. If $r \geq r_{\text {table }}$ is at the significance level of $5 \%$, then $\mathrm{Ha}$ is accepted, and $\mathrm{Ho}$ is rejected.

Table 5. Hypothesis Test Results with the Product Moment Correlation Formula

Correlations

\begin{tabular}{|llll}
\hline & & \multicolumn{1}{c}{ Kemampuan } & Kreativitas \\
& & \\
\hline Denari \\
Ability & Pearson & 1 &, $543^{* *}$ \\
\cline { 2 - 3 } & Sig. (2-tailed) & \\
\cline { 2 - 3 } $\mathrm{N}$ & 30 & 30 \\
\hline Creativity & Pearson &, $543^{* *}$ & 1 \\
\cline { 2 - 3 } & Sig. (2-tailed) &, 002 & \\
\cline { 2 - 3 } $\mathrm{N}$ & 30 & 30
\end{tabular}

**. Correlation is significant at the 0.01 level (2-tailed). From the table above, a Pearson Correlation 0.543 obtained means that there are a significant relationship and $\mathrm{P}$-value 0.002 . Because the $\mathrm{P}$-value $<0.05$, it can be concluded that there is a significant relationship between creativity with the ability to dance and has a strong close relationship. This means that the higher the creativity, the higher the ability to dance.

\section{Discussion}

This study aims to determine whether there is a relationship between creativity with the ability to dance in fourth-grade students. Seen from the result of hypothesis testing shows that there is a significant positive relationship between creativity and dancing ability with a value of 0.543 . This means that student creativity has a relationship with the ability to dance. Based on the results of data analysis, a positive correlation coefficient is obtained by showing the relationship between creativity and the ability to dance positively. This means that the higher the creativity, the higher the ability to dance. In accordance with the statement of Tri Diny Inscription (2015: 69) said that the ability to dance must have ideas of creativity that can help the development of abilities and talents possessed by students. Students who have creativity will be fluent in thinking to create dance movements, flexible thinking to combine dance movements with rhythm, can think in an original and elaborative way so that they can think original and detailed in creating different and interesting movements. In contrast to students who have low creativity, students will find it difficult to find interesting ideas in creating dances, and it is difficult 
to combine movements with rhythm, and tend to mimic existing movements.

Thus, creativity plays an important role in the ability to dance so students can obtain optimal dance movements. If more, the higher the creativity of students, the higher the ability to dance. Based on the results of the hypothesis test of 0.543 shows that there is a significant relationship between students' creativity with the ability to dance. Thus the alternative hypothesis $(\mathrm{Ha})$ is accepted.

\section{CONCLUSION}

Based on the results of the research analysis and the data above, it can be concluded that there is a positive relationship between creativity with the ability to dance class IV SDN Telukjambe Cluster 01 East TelukJambe District Karawang Regency indicated by the correlation coefficient value of 0.543 at the moderate level of relationship. Students who have creativity will be fluent in thinking to create dance movements, flexible thinking to combine dance movements with rhythm, can think in an original and elaborative way so that they can think original and detailed in creating different and interesting movements. In contrast to students who have low creativity, students will find it difficult to find interesting ideas in creating dances, and it is difficult to combine movements with rhythm, and tend to mimic existing movements.

\section{REFERENCES}

Anggraeni, S.W., \& Alpian, Y. (2018). Pendidikan Seni Tari Dan Drama.Banten: Desanta Muliavisitama

Hadi, Y. , \& Sumandiyo. (2011). Koreografi: Bentuk - Teknik - Isi. Yogyakarta: Cipta Media.

Haryono,S. (2012). Konsep Dasar Bagi Seorang

Penari. Jurnal Greget. Volume 11 No. 1 Juli 2012 Munandar U.(2014). Pengembangan Kreativitas Anak Berbakat. Jakarta: PT Rineka Cipta.

Nana Syaodih Sukmadinata. 2004. Landasan Psikologi Proses Pendidikan. Bandung:Remaja Rosdakarya.

Panggayuh,H.C. 2016. Pencapaian Kompetensi Dasar Dalam Pembelajaran Seni Tari Pada Siswa Kelas X Ipa 2 Di Sma Negeri 1 Kotagajah. Skripsi. Universitas Lampung.

Prastini, D.T. (2015). Hubungan Bakat dan Kreativitas dengan Kemampuan Menciptakan Tari pada Siswa Kompetensi Keahlian Seni Tari SMK Negeri 1 Kasihan Bantul. Thesis. Universitas Negeri Yogyakarta.

Rohani. (2012). Meningkatkan Kreativitas Anak Usia Dini Melalui

Media Bahan Bekas. Jurnal Raudhah: Issn: 23382163 - Vol. 05, No. 02 Juli-Desember 2017.

Slameto. (1995). Belajar dan FaktorFaktor yang Mempengaruhinya. Jakarta : Rineka Cipta.

Soedarsono. (2002). Seni Pertinjukan Indonesia

Diera Globalisasi. Jogjakarta: Gajah Mada University Press

Widaryanto,FX. (2007). Antropologi Tari. Bandung:Sunan Ambu Pres. 
Yusuf S dan Sugandhi N.M2014).Perkembangan

Peserta Didik. Depok: PT Raja Grafindo Persada 